\title{
Field evaluation of the relative susceptibility of six pear varieties to the pear psylla (Cacopsylla pyricola (Foerster, 1848))
}

\author{
Mohammad Saeed EMAMI ${ }^{1,2}$
}

Field evaluation of the relative susceptibility of six pear varieties to the pear psylla (Cacopsylla pyricola (Foerster, 1848))

Abstract: The pear psylla, Cacopsylla pyricola (Foerster, 1848) (Hemiptera: Psyllidae), is one of the most detrimental pests in commercial pear orchards. Varieties with low infestation level to pear psylla would offer to integrated psyllid management. The natural infestation level of six pear varieties to pear psylla was studied under field conditions during three successive years. The pear varieties consisted of 'Comice', 'Buerre Giffard', 'Bonne Louise,' 'Felestini,' 'Shahmiveh', and 'Sebri'. Psyllid population was sampled weekly by limb jarring method and selecting 10 leaves randomly per tree. The results indicated that the size of the psyllid population on the tested pear varieties was significantly different $\left(F_{5,30}=816.18, p<0.0001\right)$. 'Shahmiveh' and 'Sebri' showed high and low susceptible, respectively, to pear psylla infestation. The natural infestation level of $C$. pyricola was $37.01 \%$ and $35.8 \%$ lower on 'Bonne Louise' and 'Sebri', respectively, than on 'Shahmiveh'. These varieties may be used for crossing in breeding programs to develop plant resistance to C. pyricola and may be exploited in integrated psyllid management. variety

Key words: pear psylla; population; relative susceptibility,
Received February 04, 2019; accepted August 02, 2019. Delo je prispelo 04. februarja 2019, sprejeto 02. avgusta 2019.

Ovrednotenje relativne občutljivosti šestih sort hrušk na malo hruševo bolšico (Cacopsylla pyricola (Foerster, 1848))

Izvleček: Mala hruševa bolšica, Cacopsylla pyricola (Förster, 1848) (Hemiptera: Psyllidae), je eden izmed najbolj uničujočih škodljivcev v komercialnih nasadih hrušk. Sorte z majnim deležem okužbe $\mathrm{z}$ bolšico bi lahko uporabili pri integriranem upravljanju s hruševo bolšico. Naravna okužba s hruševo bolšico je bila preučevana na šestih sortah hrušk na prostem v treh zaporednih letih. Sorte hrušk so bile:'Comice', 'Buerre Giffard', 'Bonne Louise, 'Felestini', 'Shahmiveh', in 'Sebri'. Populacija bolšic je bila vzorčena tedensko s stresanjem vej in naključno izbiro 10 listov na drevo. Rezultati so pokazali, da so bile velikosti populacij bolšice na preučevanih sortah hrušk značilno različne $\left(F_{5,30}=816,18, p<0,0001\right)$. Sorti 'Shahmiveh' in 'Sebri' sta pokazali veliko in manjšo občutljivost na okužbo $s$ hruševo bolšico. Naravni okužbi s hruševo bolšico sta bili na sortah 'Bonne Louise' in 'Sebri' za 37,01 \% in 35,8 \% manjši kot na sorti 'Shahmiveh. Ti sorti bi lahko uporabili za križanja v žlahtniteljskih programih za razvoj odpornosti hrušk na bolšico in jih uporabili pri integriranem upravljanju $\mathrm{z}$ bolšico.

Ključne besede: hruševa bolšica; populacija; relativna občutljivost; sorta

1 Isfahan Agriculture and Natural Resources Research and Education Center, Department of Plant Protection, AREEO, Isfahan, Iran

2 Corresponding author, e-mail: mse1480@gmail.com 


\section{INTRODUCTION}

The pear psylla, Cacopsylla pyricola (Förster, 1848) (Hemiptera: Psyllidae), is a main insect pest of the planted pear (Pyrus communis L.) in the production areas of Iran (Emami, 2016), North America and Europe (Bell, 2013) with the greatest economic importance (Emami et al., 2014b). The immature psyllids and adults feed by sucking out the plant sap. Psyllids feeding cause to excrete large amounts of honeydew on leaves and fruits, pear tree growth inhibition, leaf necrosis, diminished fruit size, young fruit russetting and premature fruit fall, resulting in considerable losses in crop yield (Emami et al., 2014b). Pear psylla also carries the disease pear decline, which can affect tree health and lead to death of the tree (Sule et al., 2007). Heavy and prolonged feeding and the injection of toxic saliva by enormous populations can cause partial to whole defoliation of pear trees, reducing vitality and inhibiting the formation of fruit buds in the following season. Psyllid invasion is the greatest pest management problem of pear orchards in Iran (Emami et al., 2014a). Since the pear psyllid are able to develop resistance to chemical insecticides (Pree et al., 1990) the domain of effective insecticides for its suppression is limit and the used concentrations are continuously increasing, on the contrary consumers request lower insecticide utilization on the pear crop. Hence investigate on varieties with durable and natural resistance to pear psyllid is an efficient and sustainable strategy for inclusion in pear psylla integrated pest management program. Chang and Philogene (1976) showed that pear psyllid laid more eggs on 'Bosc' cultivar than 'Anjou', 'Bartlett', 'Kieffer' and Pyrus ussuriensis Maxim. Cultivar 'Kieffer' was sig- nificantly less desirable as hosts for pear psyllid. Quarta and Puggioni (1985) surveyed on 93 cultivars and 43 selections grown in the variety testing trial. They showed that the most common varieties are all very susceptible to pear psylla and only $12 \%$ showed a low susceptibility. Shaltiel-Harpaz et al. (2013) evaluated two pear accessions to pear psylla and indicated that evaluated accessions are more resistant than the commercial cultivar 'Spadona.' The present study was done to evaluate the relative susceptibility of six pear varieties to the pear psylla under natural infestation conditions with the purpose to employ in the psyllid management.

\section{MATERIALS AND METHODS}

\subsection{SITE AND PLANTS}

Field assays were carried out in a 1-ha commercial pear orchard placed at Mobarakeh research station (Isfahan, Iran), during the three successive growing seasons (2010-2012) on 25 year-old pear trees. The pear varieties consisted of 'Comice', 'Buerre Giffard,' 'Bonne Louise,' 'Felestini', 'Shahmiveh', and 'Sebri'. They were nearly an average of $4 \mathrm{~m}$ in height, with $5 \mathrm{~m}$ spacing between plants. Management activities including suppression of other pests, fertilization, pruning and irrigation were performed alike on all pear trees. No insecticides were utilized during the years of study on the pear trees.

\subsection{EXPERIMENTAL DESIGN}

The experiment was organized in a completely randomized block design with three replicates.

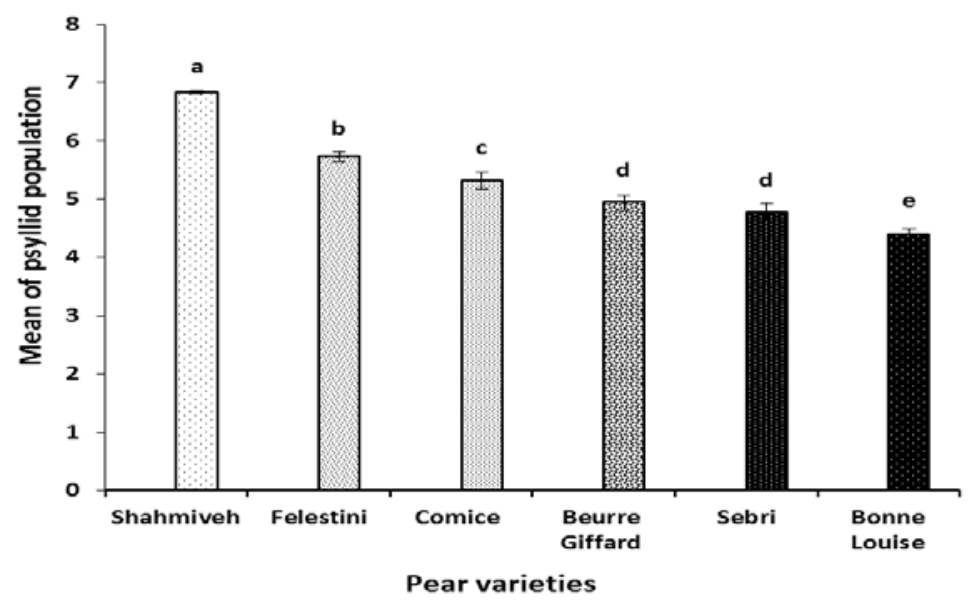

Figure 1: Mean $( \pm$ SE) of psyllid population (eggs + nymphs + adults) on the pear varieties under natural infestation conditions in 2010. Columns with different letters differ significantly at $p<0.05$ (Duncan's multiple range test). 


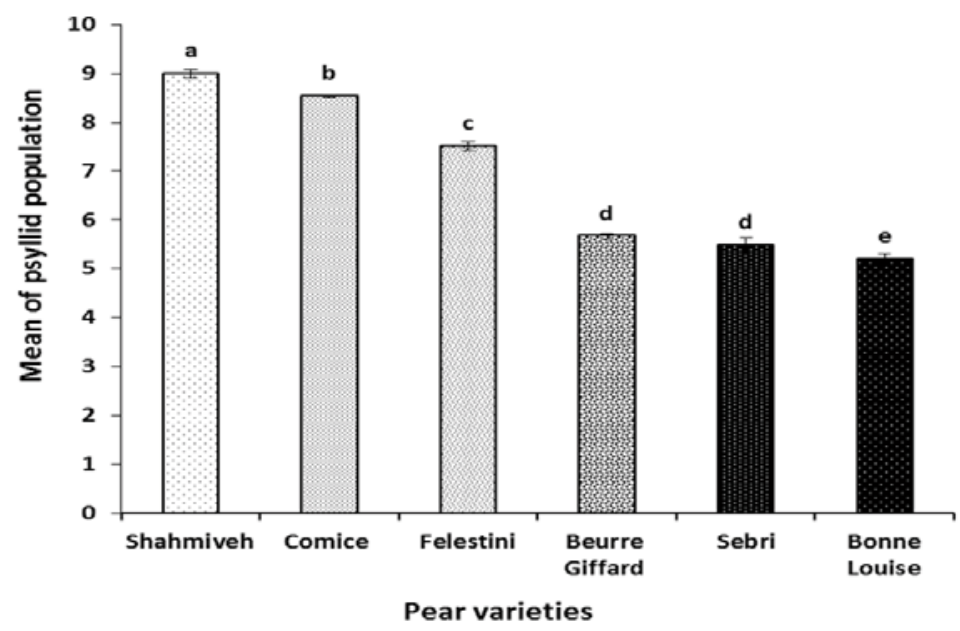

Figure 2: Mean of psyllid population (eggs + nymphs + adults) on the pear varieties under natural infestation conditions in 2011. Columns with different letters differ significantly at $p<0.05$ (Duncan's multiple range test).

\subsection{SAMPLING}

Adults of pear psylla were randomly collected from four branches using the limb beating technique (Burts and Retan, 1973). Sampling was done in the morning when adult flight was limited. Each branch was tapped three times with a piece of hard rubber hose and all psyllid falling on the beat tray were counted. Populations of eggs and nymphs in pre bloom stage were counted by getting shoot samples. Four young branches per tree, approximately $25 \mathrm{~cm}$ in length, were randomly sampled from different geographical directions. Following foliar expansion of the buds, 10 leaves were randomly selected per tree. Samplings were done weekly. The samples were separately put into nylon bag, moved to the laboratory in an ice box, carefully inspected under a binocular and pear psyllid eggs and nymphs were enumerated and registered.

\subsection{DATA ANALYSES}

The data were square root $(\mathrm{x} \pm 0.5)$ transformed before analysis to standardize the variance, and then subjected to one-way ANOVA. The comparison of psyllid population was performed using Duncan's multiple range test (DMRT) $(p<0.05)$. All analyses were performed using SAS statistical software version 9.1. (SAS Institute Inc. 2004).

\section{RESULTS}

\subsection{THE PEAR PSYLLID POPULATION ON THE VARIETIES IN THE FIRST YEAR}

There was a significant difference among varieties in term of pear psyllid population $\left(F_{5,10}=128.15, p<0.0001\right)$. The comparison of population means showed that the pear varieties were categorized into five groups (Fig. 1). The natural infestation levels of $C$. pyricola on 'Bonne Louise' and 'Shahmiveh' was the lowest and the highest, respectively (Fig. 1).

\subsection{THE PEAR PSYLLID POPULATION ON VARIE- TIES IN THE SECOND YEAR}

The pear psyllid population showed a significant difference among tested pear varieties $\left(F_{5,10}=725.34, p<0.0001\right)$. According to the comparison of means of pest population, the pear varieties were placed into five groups (Fig. 2). The natural infestation level of $C$. pyricola on 'Bonne Louise' was nearly two times lower than on 'Shahmiveh' (Fig. 2).

\subsection{THE PEAR PSYLLID POPULATION ON VARIE- TIES IN THE THIRD YEAR}

A significant difference was found among tested varieties in relation to pear psyllid population $\left(F_{5,10}=217.17, p<\right.$ $0.0001)$. Means comparison of pest population revealed that the pear varieties were listed into five groups (Fig. 3). The natural infestation level of C. pyricola on 'Sebri' and 'Beurre Giffard' was the same and both varieties had the lowest population than others (Fig. 3).

\subsection{COMBINED ANALYSIS OF VARIANCE FOR THREE YEARS}




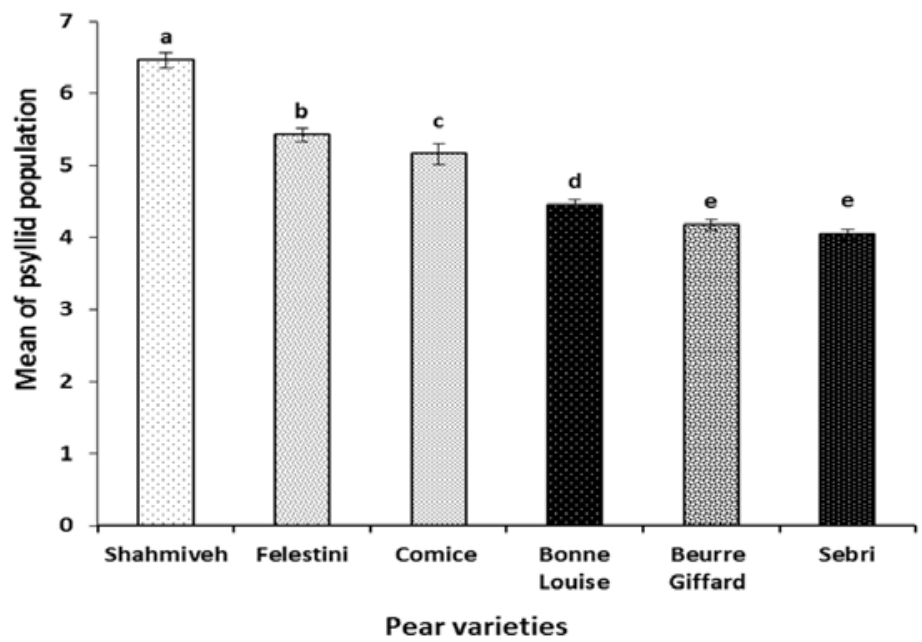

Figure 3: Mean of psyllid population (eggs + nymphs + adults) on the pear varieties under natural infestation conditions in 2012. Columns with different letters differ significantly at $p<0.05$ (Duncan's multiple range test).

Pest population had a significant difference among experimental varieties $\left(F_{5,30}=816.18, p<0.0001\right)$. The comparison of population means demonstrated that the pear varieties categorized into five groups (Fig. 4). The natural infestation level of $C$. pyricola was $37.01 \%$ and $35.8 \%$ lower on 'Bonne Louise' and 'Sebri', respectively, than on 'Shahmiveh' (Fig. 4).

\section{DISCUSSION}

C. pyricola is presently a very tiresome problem in pear-growing regions. It appears with two to five popu- lation peaks from spring to autumn depending upon latitude (Horton, 2008; Hodkinson, 2009; Emami, 2016). The cost of chemical control per hectare is annually high (Bell, 2013). Pear trees with persistent resistance would improve the economic and environmental durability of pear production by decreasing producer costs and insecticides use. Host resistance in pear tree to the pear psyllid (Cacopsylla sp.) can be described under natural infestation conditions on the basis of the pest population size at specific periods (Bell and Puterka, 2004). We noticed, three years study revealed that the size of the psyllid population on the tested pear varieties was significantly different (Fig. 1-4). No immunity to pear psyllid was found.

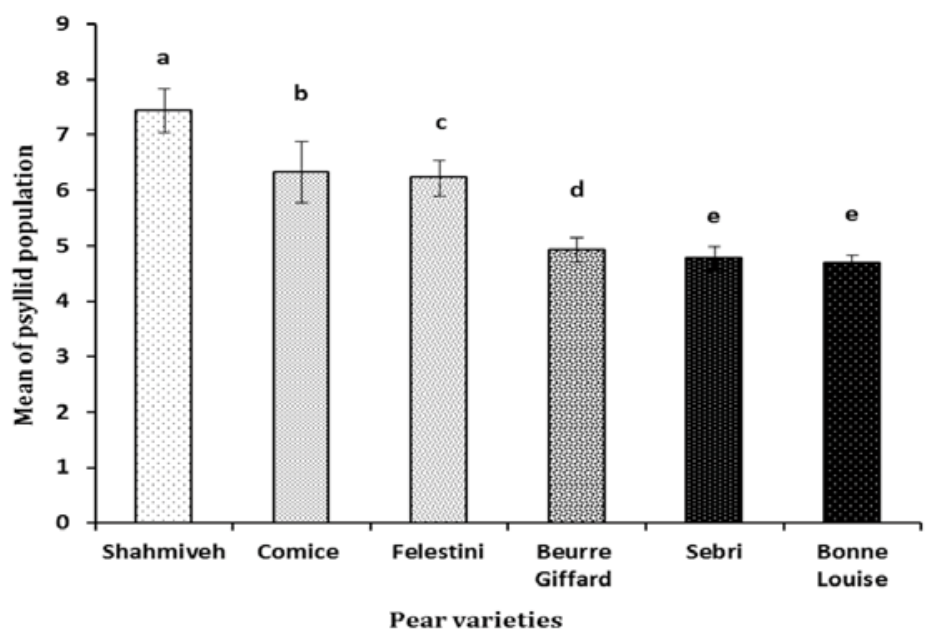

Figure 4: Mean of psyllid population (eggs +nymphs + adults) on the pear varieties under natural infestation conditions in three years study. Columns with different letters differ significantly at $p<0.05$ (Duncan's multiple range test). 
Although none were immune but there was a variation in varieties in their susceptibility to the psyllid. Plants are often varying in their susceptibility to the associated psylla species, arranging across a spectrum from highly susceptible to close resistant (Hodkinson, 2009). In our trial, 'Shahmiveh' variety was very susceptible and vulnerable to psyllid attack (Fig. 1-4). Radjabi (1989) described that the intensity of the pear psyllid population and injuries of pear psylla was high on 'Shahmiveh' variety. Variation in susceptibility can happen across varieties within single species of host plant (Hodkinson, 2009). 'Felestini' and 'Comice' varieties, which were observed in our research, were susceptible varieties. 'Comice' is one of the main pear varieties in many countries and was reported as a susceptible host plant to pear psyllid (Bellini and Nin, 2002; Fischer, 2009). Nin et al. (2015) reported that 'Comice' suffered medium injuries to psylla attack and classified into medium susceptible class. Cross breeding between 'NY10353' as male parent and 'Comice' as female parent has shown a great degree of psylla resistance in controlled conditions (Musacchi et al., 2005; Pasqualini et al., 2006). Behavioral investigations mention that pear psyllid adults use tactile cues to discover chemicals within the tree or on its surface proper for host choice, feeding, and oviposition (Ullman and McLean 1988; Horton, 1990; Horton and Krysan, 1991). Berrada et al. (1995) reported that under field conditions 'Comice' variety was classified as susceptible variety to pear psylla. Westigard et al. (1981) reported that russeted varieties are less susceptible to damage due to honeydew than are smooth-skinned varieties such as 'Comice'. On the contrary, Gerard et al. (1993) showed that resistance is not directly proportional to leaf cuticle thickness, the resistant 'NY' for example has a lower constituent of cutin than the susceptible 'Bartlett' variety. The psyllid population size on 'Sebri, 'Bonne Louise' and 'Buerré Giffard' varieties were lower than 'Shahmiveh' and 'Comice' (Fig. 1-4). Difference in psyllid development prosperity among host species and varieties can generally be explained by variations in the primary attractiveness of the foliage, differential oviposition ratios, larval survival ratios and larval development time (Hodkinson, 2009). Braniste et al. (1994) described 'Buerré Giffard' was slightly attacked by psylla. Horton and Krysian (1991) demonstrated that psyllid is more selective in its oviposition behaviors than in its settling and probing behaviors; i.e., probing is not probably to be a symptom of a variety's acceptability. They also reported that the cues excite feeding activity vary from those for egg laying. Here, the pear psyllid adults had settling and probing activities on later pear varieties but psyllid population did not increase on these than 'Shahmiveh' and 'Comice.' The pear psyllid can colonize and feed on non- desired host plants, but they do not lay eggs (Pasqualini et al., 2006). 'Sebri' variety showed medium susceptible to pear psylla infestation and damage. This finding is in accordance with Radjabi (1989) who described 'Sebri' is a partially resistant host plant to pear psylla damage. Braniste et al. (1994) described 'Buerré Giffard' was slightly attacked by psylla. Aksic et al. (2015) reported that the levels of polyphenolics are most likely responsible for pear resistance to psylla. Resistance of deciduous plants to phloem feeding insects is supposed to result from a combination of structural and excited physical and chemical guards (Eyles et al., 2007). Host resistance has long been regarded as the best alternative and ecologically secure outlook to chemical control of pear psyllid (Civolani et al., 2013). Some of these varieties may be exploited in organic farming combined with biological control. It is suggested that additional studies should be carried out to analyze the morphological and chemical structure of pear cultivars to further characterize the resistance of these cultivars.

\section{REFERENCES}

Aksić M.M.F., Dabić D.C., Gašić U.M., Zec G.N., Vulić T.B., Tesić Z.L., Natić M.M. (2015). Polyphenolic Profile of Pear Leaves with Different Resistance to Pear Psylla (Cacopsylla pyri). Journal of Agricultural and Food Chemistry, 63, 74767486. https://doi.org/10.1021/acs.jafc.5b03394

Bell R.L., Puterka G.J. (2004). Modes of host plant resistance to pear psylla: a review. Acta Horticulturae, 663, 183-188. https://doi.org/10.17660/ActaHortic.2004.663.26

Bell R.L. (2013). Host resistance to pear psylla of breeding program selections and cultivars. Horticultural Science, 48, 143-145. https://doi.org/10.21273/HORTSCI.48.2.143

Bellini E., Nin S. (2002). Breeding for new traits in pear. Acta Horticulturae, 596, 217-224. https://doi.org/10.17660/ActaHortic.2002.596.31

Berrada S., Nguyen T.X., Lemoine J., Vanpoucke J., Fournier D. (1995). Thirteen pear species and cultivars evaluated for resistance to Cacopsylla pyri (Homoptera: Psyllidae). Environmental Entomology, 24, 1604-1607. https://doi. org/10.1093/ee/24.6.1604

Braniste N., Amzar V., Radulescu M., Sugar D. (1994). Resistance sources to Psylla sp. Acta Horticulturae, 367, 54-63. https://doi.org/10.17660/ActaHortic.1994.367.6

Burts E.C., Retan H.A. (1973). Detection of pear psylla. Washington State University, Cooperative Extension Service Mimeo 3069, Pullman, WA, 2 pp.

Chang J.F., Philogene B.J.R. (1976). The development and behavior of the Psylla pyricola on different rootstocks and cultivars. Phytoprotection, 57, 127-149.

Civolani S., Grandi G., Chicca M., Pasqualini E., Fano E.A., Musacchi S. (2013). Probing behaviour of Cacopsylla pyri on a resistant pear selection. Journal Applied Entomology, 137, 365-375. https://doi.org/10.1111/jen.12003

Emami M.S. 2016. Field evaluation of two biorational compounds in the control of pear psylla, Cacopsylla pyricola 
(Förster), on pear trees. Archives of Phytopathology and Plant Protection, 49, 11-18. https://doi.org/10.1080/032354 08.2016.1147122

Emami M.S., Shishehbor P., Karimzadeh J. (2014a). The influences of plant resistance on predation rate of Anthocoris nemoralis (Fabricius) on Cacopsylla pyricola (Förster). Archives of Phytopathology and Plant Protection, 47, 20432050. https://doi.org/10.1080/03235408.2013.868695

Emami M.S., Shishehbor P., Karimzadeh J. (2014b). Functional response of Anthocoris nemoralis (Hemiptera: Anthocoridae) to the pear psylla, Cacopsylla pyricola (Hemiptera: Psyllidae): effect of pear varieties. Journal of Crop Protection, 3, 597-609.

Eyles A., Jones W., Riedl K., Cipollini D., Schwartz S., Chan K., Herms D.A., Bonello P. (2007). Comparative phloem chemistry of Manchurian (F. mandshurica) and two North American ash species (F. americana and F. pennsylvanica). Journal of Chemical Ecology, 33, 1430-1448. https://doi. org/10.1007/s10886-007-9312-3

Fischer M. (2009). Pear breeding. pp.1-26. In: S. Mohan Jain and P. M. Priyadarshan [Eds.], Breeding Plantation Tree Crops: Temperate Species. Springer, New York, 290 pp.

Gerard H.C., Fett W.F., Moreau R.A., Osman F.S., Miller R.L. (1993). Chemical and enzymic investigation of the leaf cuticle of pear genotypes differing in resistance to pear psylla. Journal of Agricultural and Food Chemistry, 41, 2437-2441. https://doi.org/10.1021/jf00036a043

Hodkinson I.D. (2009). Life cycle variation and adaptation in jumping plant lice (Insecta: Hemiptera: Psylloidea): a global synthesis. Journal of Natural History, 43, 65-179. https:// doi.org/10.1080/00222930802354167

Horton D.R., Krysan, J.L. (1991). Host acceptance behavior of pear psylla (Homoptera: Psyllidae) affected by plant species, host deprivation, habituation, and egg load. Annals of the Entomological Society of America, 84, 612-627. https:// doi.org/10.1093/aesa/84.6.612

Horton D.R. (1990). Oviposition by overwintering morph of pear psylla (Homoptera:Psyllidae) with information on conditioning. Environmental Entomology, 19, 357-361. https://doi.org/10.1093/ee/19.2.357

Horton D.R. (2008). Pear psylla, Cacopsylla pyricola (Foerster) (Hemiptera: Psyllidae). pp. 2772-2775. In: J. L. Capinera (Ed.), Encyclopedia of Entomology. 2nd. Ed. Vols. 1-4. Springer, Dordrecht, The Netherlands, 4346 pp.
Musacchi S., Ancarani V., Gamberini A., Giatti B., Sansavini S. (2005). Progress in pear breeding at the University of Bologna. Acta Horticulturae, 671, 191-194. https://doi. org/10.17660/ActaHortic.2005.671.24

Nin S., Ferri A., Sacchetti P., Picardi E., Cantini C., Giordani E. (2015). Susceptibility of European pear germplasm to $\mathrm{Ca}$ copsylla pyri under mediterranean climatic conditions. Scientia Horticulturae, 185, 151-161. https://doi.org/10.1016/j. scienta.2015.01.031

Pasqualini E., Civolani S., Musacchi S., Ancarani V., Dondini L., Robert P., Baronio P. (2006). Cacopsylla pyri behaviour on new pear selections for host resistance programs. Bulletin of Insectology, 59, 27-37.

Pree D.J., Archibald K.W., Ker K.W., Cole K. J. (1990). Occurrence of Pyrethroid resistance in pear psylla (Homoptera: Psyllidae) populations in southern Ontario. Journal of Economic Entomology, 83, 2159-2163. https://doi.org/10.1093/ jee/83.6.2159

Quarta R., Puggioni D. (1985). Survey on the variety susceptibility to pear Psylla. Acta Horticulturae, 159, 77-86. https:// doi.org/10.17660/ActaHortic.1985.159.10

Radjabi Gh. (1989). Insects attacking rosaceous fruit trees in Iran: Homoptera. Vol. 3. Plant Pests and Diseases Research Institute, Tehran, Iran, $256 \mathrm{pp}$

SAS Institute Inc. (2004). SAS/STAT user's guide. Version 9.1 ed. SAS Institute, Cary, North Carolina, $5121 \mathrm{pp}$.

Shaltiel-Harpaz L., Soroker V., Kdoshim R., Hason R., Sakalsky T., Hatib K., Bar-Yałakov I., Holland D. 2013. Two pear accessions evaluated for susceptibility to pear psylla Cacopsylla bidens (Šulc) in Israel. Pest Management Science, 70, 234-239. https://doi.org/10.1002/ps.3543

Sule S., Jenser G., Szita E. (2007). Management of pear decline caused by Candidatus Phytoplasma pyri in Hungary. Bulletin of Insectology, 60, 319-320.

Ullman D.E., McLean D.L. (1988). Feeding behavior of the winterform pear psylla, Psylla pyricola (Homoptera: Psyllidae), on reproductive and transitory host plants. Environmental Entomology, 17, 675-678. https://doi.org/10.1093/ ee/17.4.675

Westigard P.H., Allen R.B., Gut L.J. (1981). Pear psylla: relationship of early-season nymph densities to honeydew-induced fruit damage on two pear cultivars. Journal of Economic Entomology, 74, 532-534. https://doi.org/10.1093/jee/74.5.532 